\title{
Effects of amiloride on the induction of DNA synthesis and casein gene expression in rabbit mammary explants
}

\author{
P Martel 1, LM Houdebine 2*
}

1 INRA, Laboratoire des Sciences de la Consommation;

2 INRA, Unité de Différenciation Cellulaire, 78350 Jouy-en-Josas, France

(Received 23 May 1989; accepted 25 October 1989)

\begin{abstract}
Summary - Amiloride, an inhibitor of $\mathrm{Na}+/ \mathrm{H}+$ exchange, was added at various concentrations to the culture medium of rabbit mammary explants. In the concentration range of 100-250 $\mu \mathrm{M}$, amiloride progressively inhibited ${ }^{14} \mathrm{C}$-thymidine incorporation induced by insulin, EGF or prolactin. Up to $250 \mu \mathrm{M}$, amiloride, which did not inhibit basal protein synthesis, was not cytotoxic, but it reduced basal DNA synthesis at the highest concentration. Addition of amiloride to the culture medium of mammary explants also strongly inhibited the induction of casein synthesis and casein mRNA accumulation by prolactin. The inhibition by amiloride is therefore not specific of the mitogenic action of prolactin since this drug also prevented its lactogenic action. The data reported here describe a new inhibitory action of amiloride on the transmission of the lactogenic signals.
\end{abstract}

\section{amiloride / DNA synthesis / caseln gene expression}

\begin{abstract}
Résumé - Effets de l'amiloride sur l'induction de la synthèse de l'ADN et sur l'expression des gènes des caséines dans des explants mammaires de lapin. L'amiloride, un inhibiteur des échanges $\mathrm{Na}^{+} / \mathrm{H}^{+}$, a été ajouté à des concentrations variables au milieu de culture d'explants mammaires de lapin. Dans l'intervalle de concentration 100-250 $\mu \mathrm{M}$, l'amiloride inhibe progressivement l'incorporation induite par l'insuline de ${ }^{14} \mathrm{C}$-thymidine dans I'ADN, I'EGF et la prolactine. Jusqu'à 250 $\mu M$, l'amiloride, qui n'inhibe pas la synthèse proteique basale, n'est toujours pas toxique, mais il réduit la synthèse basale d'ADN aux concentrations les plus élevées. L'addition d'amiloride au milieu de culture des explants inhibe également de manière intense l'induction par la prolactine de la synthèse de caséine et l'accumulation des ARNm correspondants. L'inhibition par l'amiloride n'est donc pas spécifique de l'action mitogène de la prolactine puisque ce composé s'oppose également à son action lactogène. Les données rapportées ici décrivent un nouvel effet de l'amiloride sur la transmission du signal lactogène.
\end{abstract}

amlloride / synthèse d'ADN / expression des gènes des caséines

\footnotetext{
* Correspondence and reprints
} 


\section{INTRODUCTION}

The major part of the development of the mammary gland takes place during pregnancy. It involves the multiplication and differentiation of the mammary epithelium which leads to the formation of the alveoli, specialized in the synthesis and secretion of milk components. The factors which control the mammary gland growth are multiple and include at least insulin, EGF and prolactin (Martel and Houdebine, 1982). The mitogenic actions of these 3 polypeptides can be studied in vitro using rabbit mammary explants (Martel and Houdebine, 1982). In this system, although insulin and EGF are mitogenic when added alone to the synthetic culture medium, the mitogenic action of prolactin is observed only in the presence of insulin and cortisol. In addition, EGF exerts a synergic effect on the mitogenic actions of insulin and prolactin. The 3 polypeptides thus appear to control the multiplication of mammary cells by complementary mechanisms. On the other hand, prolactin not only favours the growth of the mammary gland, but also plays a key role in its differentiation. Indeed, prolactin is essential for the initiation of milk synthesis in all species. Whether both mitogenic and lactogenic actions of prolactin are delivered by the same mechanism is still unknown. The nature of the mediators responsible for the mitogenic actions of insulin, EGF and prolactin still remains to be discovered. One attractive hypothesis is that the mitogenic signal is mediated by intracellular $\mathrm{pH}$ changes resulting from ion fluxes. Indeed, ion fluxes are one of the early biochemical events which can be detected just after the addition of growth factors to the culture medium of quiescent cells (Rozengurt, 1983): for example, prolactin, EGF and insulin enhance the influx of the $\mathrm{Na}^{+}$ions in their target cells (Bisbee, 1981; Pouyssegur et al, 1982; Moolenaar et al, 1984).
Thus, the $\mathrm{Na}+/ \mathrm{H}+$ exchange leading to the rise of the intracellular $\mathrm{pH}$ has been postulated to play an essential role in the triggering of mitosis by growth factors (Pouyssegur et al, 1982; Schuldiner and Rozengurt, 1982). This hypothesis is supported by experiments in which direct measurements of intracellular $\mathrm{pH}$ have been carried out. It also relies on the use of amiloride, a strong diuretic drug, which inhibits the $\mathrm{Na}+/ \mathrm{H}+$ exchange (Koch and Leffert, 1979; La Belle and Eaton, 1983).

Whether the proposed mechanism is involved in the mitogenic action of one of the 3 polypeptides was tested in rabbit mammary explants. For that purpose, the effect of amiloride on the stimulation of DNA synthesis by insulin, EGF and prolactin was studied. The effect of the drug on the induction of casein synthesis was also evaluated.

\section{MATERIALS AND METHODS}

\section{Culture of mammary explants}

Mammary fragments were explanted from pregnant rabbits 14 days after mating and cultured for 1 day in medium 199 in the presence of various concentrations of amiloride (Merck Sharp and Dohme-Chibret) and with or without hormones. Amiloride was dissolved in dimethylsulfoxide. Bovine insulin (Sigma), EGF (collaborative Research Incorporation), ovine prolactin (NIH-PS9) and cortisol (Roussel-Uclaf) were added to the culture medium at concentrations of $5 \mu \mathrm{g} / \mathrm{ml} 100 \mathrm{ng} / \mathrm{ml}, 100 \mathrm{ng} / \mathrm{ml}$ and $500 / \mathrm{ng} / \mathrm{ml}$, respectively.

\section{DNA synthesis}

At the end of the culture, [14C]thymidine ( $54 \mathrm{mCi} / \mathrm{mmol}, \mathrm{CEA}$ ) was added to the medium $(1 \mu \mathrm{Ci} / \mathrm{ml})$ and the culture was pursued for $2 \mathrm{ad}-$ ditional $h$. The explants were then collected, weighed and digested overnight by $0.5 \mathrm{M}$ $\mathrm{NaOH}$. DNA was precipitated by $5 \%$ trichloroa- 
cetic acid, collected on glass fiber filters and the radioactivity was estimated by scintillation counting.

\section{Total protein synthesis}

At the end of the culture, $14 \mathrm{C}$-amino acids (Chlorella hydrolysate, $1.5-2 \mathrm{mCi} / \mathrm{mg}, \mathrm{CEA}$ ) were added to the medium and the culture was pursued for $\mathbf{2}$ additional hours. Radioactivity was estimated as described above for DNA synthesis.

\section{Casein synthesis and casein mRNA concentration}

At the end of culture, tissue was collected and homogenized in a phosphate buffer containing Triton and the content of $\beta$-casein in the homogenate was evaluated using a radioimmunoassay with goat anti-rabbit $\beta$-casein and rabbit anti-goat immunoglobulin.

The concentration of $\beta$-casein mRNA in total nucleic acids from explants was estimated at the end of cultures by hybridization with a labelled $\beta$-casein cDNA probe inserted into a plasmid (Martel et al, 1983a).

\section{Quantification of prolactin receptors}

125l-hGH taken as the lactogenic hormone $(50 \mu \mathrm{Ci} / \mathrm{ug})$ was incubated with crude microsomes prepared after culture of explants in the presence of insulin, with or without prolactin and amiloride. After an overnight incubation at $25{ }^{\circ} \mathrm{C}$ (100 $000 \mathrm{cpm}$ labelled hormone, with $200 \mu \mathrm{g}$ membrane protein), membranes were pelleted and the radioactivity specifically bound to membranes was evaluated. When no culture was carried out, crude mammary microsomes were prepared from a lactating rabbit, and incubated with labelled hGH in the presence or in the absence of amiloride as mentioned above.

\section{RESULTS}

\section{Effect of amiloride on DNA synthesis}

Insulin, EGF and prolactin significantly stimulated $[14 \mathrm{C}]$ thymidine incorporation into DNA in rabbit mammary explants. Amiloride was added at various concentrations to the culture medium to study its effects upon the transmission of the 3 mitogenic signals. Amiloride, in the concentration range of $100-250 \mu \mathrm{M}$ progressively inhibited [14C]thymidine incorporation induced by insulin, EGF or prolactin (fig 1). At these concentrations, amiloride was not cytotoxic since at levels up to $250 \mu \mathrm{M}$, basal protein synthesis was not affected (not shown). Nevertheless, amiloride action was not entirely specific since it strongly reduced the basal DNA synthesis, independently of the hormonal induction at the highest concentration. This effect on basal DNA synthesis does not seem to be due simply to the inhibition of the thymidine uptake by explants which re-

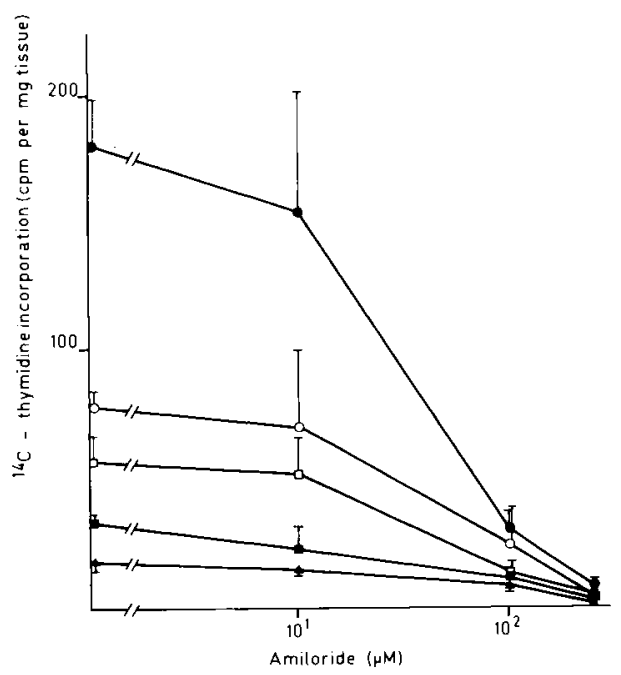

Fig 1. Effect of various concentrations of amiloride on DNA synthesis. Mammary explants were cultured without or in the presence of hormones, alone or in combination. Insulin, EGF, prolactin and cortisol were added at $5 \mu \mathrm{g} / \mathrm{ml}, 100 \mathrm{ng} / \mathrm{ml}$, $100 \mathrm{ng} / \mathrm{ml}$ and $500 \mathrm{ng} / \mathrm{ml}$ respectively. Results, which are the mean ( \pm SEM) of 3 independent cultures are expressed as $\mathrm{cpm} / \mathrm{mg}$ tissue. ( $\Delta-$ $\Delta)$ without hormone; ( $\left(-\square^{-}\right)$EGF; ( $(\square-D)$ (insulin; $(0-0)$ insulin + cortisol; (-) insulin + prolactin + cortisol. 
mained unaffected by the drug (data not shown). At $100 \mu \mathrm{M}$, amiloride did not significantly reduce the basal DNA synthesis whereas it completely inhibited the actions of the 3 mitogenic factors.

\section{Effect of amiloride on casein synthesis}

The induction of casein synthesis and the accumulation of the corresponding mRNAs is under the control of prolactin. As a control, it seemed of interest to examine the possible side-effects of amiloride on the transmission of the lactogenic prolactin message to casein genes. Amiloride inhibited the lactogenic action of prolactin as efficiently as its mitogenic action, as judged by its capacity to block the induction of casein synthesis (fig 2). This result was confirmed by the observation that it also prevented the $\beta$-casein mRNA accumulation induced by prolactin (fig 3 ).

\section{Effect of amiloride on prolactin recep- tors}

Since amiloride inhibits both prolactin actions, it is conceivable that its inhibitory effect took place directly at the plasma membrane level. Although amiloride did not affect the binding of prolactin to its microsomal specific receptors (not shown), it slightly reduced the number of prolactin receptors in cultured mammary explants (table I). This slight reduction of the prolactin receptor number could be responsible for a small part of the inhibition by amiloride. Moreover, amiloride did not prevent the down-regulation of the receptors by prolactin (table 1).

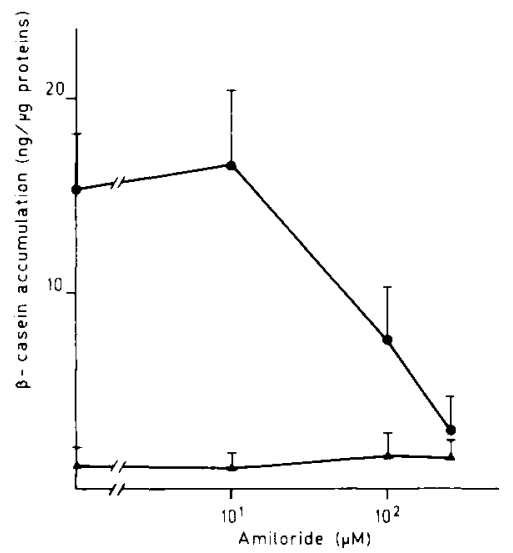

Fig 2. Effect of various concentrations of amiloride on $\beta$-casein accumulation. Mammary explants were cultured with insulin $(5 \mu \mathrm{g} / \mathrm{ml})$ and in the presence or the absence of prolactin $(100 \mathrm{ng} / \mathrm{ml})$. Results, which are the mean ( \pm SEM) of 3 independent cultures are expressed as $\mathrm{ng} \beta$-casein $/ \mu \mathrm{g}$ protein. $(\boldsymbol{\Delta}-\boldsymbol{\Delta})$ insulin; $(-)$ insulin + prolactin.

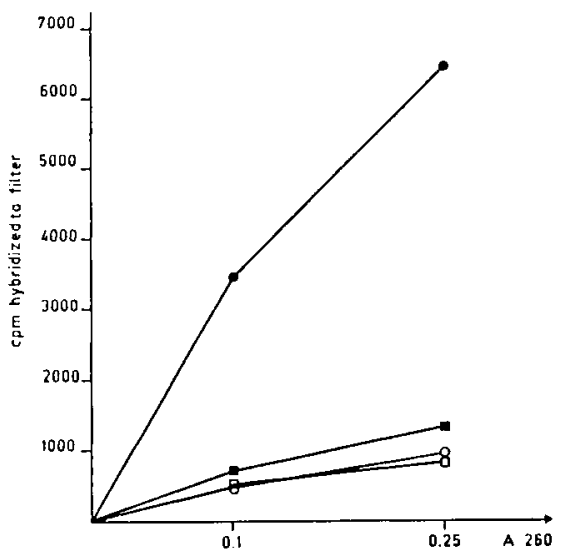

Fig 3. Effect of amiloride on the $\beta$-casein mRNA accumulation. Mammary explants were cultured in the presence of insulin $5 \mu \mathrm{g} / \mathrm{ml}$ and with or without prolactin $100 \mathrm{ng} / \mathrm{ml}$ and amiloride $250 \mu \mathrm{M}$. After 1 day culture, the $\beta$-casein mRNA concentrations were evaluated with a plasmid probe. Results are expressed as $\mathrm{cmp}$ of the probe specifically hybridized to the nitrocellulose filters. $(\mathrm{O}-\mathrm{O})$ insulin; $(\square-\square)$ insulin + amiloride; (-) insulin + prolactin; ( $\square$ ) insulin + prolactin + amiloride. 
Table I. Effect of amiloride on the number of prolactin receptors. Mammary explants were cultured for 1 day with or without insulin (I) $5 \mu \mathrm{g} / \mathrm{ml}$, prolactin (PRL) $100 \mathrm{ng} / \mathrm{ml}$ and amiloride $250 \mu \mathrm{M}$. The number of prolactin receptors was evaluated by measuring the capacity of the membranes, prepared at the end of the culture, to bind prolactin. Results are expressed as the percentage of the hormone specifically bound to membranes.

Culture medium

Prolactin receptors

(\% specific binding)

$\begin{array}{lr}\text { Control } & 12.4 \\ \text { I } & 17.2 \\ \text { I + PRL } & 8.6 \\ \text { I + amiloride } 250 \mu \mathrm{M} & 13.7 \\ \text { I + PRL + amiloride } 250 \mu \mathrm{M} & 7.4\end{array}$

\section{DISCUSSION}

The data reported here clearly indicate that amiloride inhibits the mitogenic action of prolactin. This observation is compatible with the hypothesis that $\mathrm{Na}+/ \mathrm{H}+$ exchanges are involved in the mitogenic action of prolactin as seems to be the case for other mitogenic factors (Pouyssegur et al, 1982; La Belle and Eaton, 1983). Surprisingly, however, amiloride also blocks the lactogenic action of prolactin. This either means that $\mathrm{Na}^{+} / \mathrm{H}+$ exchange is involved in the transmission of the lactogenic signal to genes or that amiloride interferes at an early unknown step of the prolactin mechanism of action which is common to the mitogenic and lactogenic signals of the hormone. If this is the case, the effects of amiloride depicted in the present report are possibly of a new type and may be added to others indirectly related to $\mathrm{Na}+/ \mathrm{H}+$ exchange (Fehlmann et al, 1981; Lubin et al, 1982; Holland et al, 1983). Interestingly, somewhat similar conclusions have been drawn from other experiments which demonstrated that colchicine (Martel and Houdebine, 1982), phorbol esters (Martel et al, 1983b) and sodium butyrate (Martel et al, 1983a) inhibited prolactin actions.
Colchicine and related drugs, phorbolesters, sodium butyrate and amiloride have no clear similarity in their chemical structure and it is not easy to imagine how these drugs could interfere with the prolactin mechanism of action. All these compounds are potentially interesting tools to study in more detail the action of prolactin at the molecular level.

\section{ACKNOWLEDGMENTS}

The authors wish to thank Mrs Marie-Louise Fontaine, Valérie François and Claudine Puissant for their technical help. This work was supported by the financial help of CNRS and INSERM and the Biotechnology Action Programme of the European Community.

\section{REFERENCES}

Bisbee CA (1981) Prolactin effects on ion transport across cultured mouse mammary epithelium. Am J Physiol 9, 110-115

Fehlmann $M$, Samson $M$, Koch KS, Leffert HL, Freychet $P$ (1981) Amiloride inhibits protein synthesis in isolated rat hepatocytes. Life Sci 28, 1295-1302 
Holland R, Woodgett JR, Grahame Hardie D (1983) Evidence that amiloride antagonizes insulin-stimulated protein phosphorylation by inhibiting protein kinase activity. Febs Lett 154, 269-273

Koch KS, Leffert HL (1979) Increased sodium ion influx is necessary to initiate rat hepatocyte proliferation. Cell 18, 153-163

La Belle EF, Eaton DC (1983) Amilorideinhibited $\mathrm{Na}+$ uptake into toad bladder microsomes is $\mathrm{Na}+\mathrm{H}^{+}$exchange. Biochim Biophys Acta 733, 194-197

Lubin M, Cahn F, Coutermarsh BA (1982) Amiloride, protein synthesis and activation of quiescent cells. J Cell Physiol 113, 247-251

Martel P. Houdebine LM (1982) Effect of various drugs affecting cytoskeleton and plasma membranes on the induction of DNA synthesis by insulin, epidermal growth factor and prolactin in mammary explants. Biol Cell 44, 111-116

Martel P, Houdebine LM, Teyssot B (1983) Effect of sodium butyrate on the stimulation of casein gene expression by prolactin. FEBS Lett 154, 55-59
Martel P, Houdebine LM, Teyssot B, Djiane J (1983) Effects of phorbol esters on multiplication and differentiation of mammary cell. Biol Cell 49, 119-126

Moolenar WH, Yarden Y, De Laat SW, Schlessinger $J(1982)$ Epidermal growth factor induces electrically silent $\mathrm{Na}+$ influx in human fibroblasts. J Biol Chem 257, 8502-8506

Pouyssegur J, Chambard JC, Franchi A, Paris $S$, Van Obberghen-Schilling $E$ (1982) Growth factor activation of an amiloride-sensitive $\mathrm{Na}+/ \mathrm{H}+$ exchange system in quiescent fibroblasts: coupling to ribosomal protein $S 6$ phosphorylation. Proc Natl Acad Sci USA 79, 3935-3939

Rozengurt E (1983) Signalling mitogenesis in 3T3 cells: role of monovalent ion fluxes and cyclic nucleotides. Cell Biol Reprod 7, 495496

Schuldiner S, Rozengurt E (1982) $\mathrm{Na}^{+} / \mathrm{H}^{+}$antiport in Swiss 3 T3 cells: mitogenic stimulation leads to cytoplasmic alkalinization. Proc Natl Acad Sci USA 79, 7778-7782 